\title{
Global Pollution, Climate Change, and Democracies
}

\author{
Jack T. Trevors
}

Published online: 20 October 2009

(C) Springer Science + Business Media B.V. 2009

Democracy is not an idea on paper or in people's minds. Democracy must be enacted internationally so humans can protect and preserve our common, shared, singular biosphere, mostly by controlling human population growth, reducing resource depletion, conservation, ending conflicts, cooperation, research, and education. There are likely no true democracies on our planet where the needs and rights of all individuals are placed before the needs of the state. So we live with the hope that we will evolve or engineer true democracies in the near future while at the same time protecting and conserving our singular, shared biosphere before it becomes unbearably hot and more overpopulated with additional hungry, suffering, and dying humans. More humans equates to more global pollution as dictated by the laws of thermodynamics. This is well understood.

Free markets, globalization, and the so-called democratic countries currently require the illusion of democracies so they can exploit resources and pollute our singular, common biosphere. Laws are passed in the so-called democratic countries that may or may not protect human and environmental health. However, in reality the laws may not be enforced, may not even exist, and the human population continues to

J. T. Trevors $(\bowtie)$

School of Environmental Sciences, University of Guelph, Guelph, OT, Canada N1G 2W1

e-mail: jtrevors@uoguelph.ca increase by 75 million annually with more pollution in the form of hydrocarbons extracted from the earth and the resulting pollution spewed back into biosphere. This is also easy to understand. Much of this is considered necessary by some people for an affluent lifestyle, national security, globalization, trade, and exploitation, and to generate profits and wealth. Democracies and free markets are intertwined. Free markets require democracies so global consumption and pollution can continue, and economic growth is achieved. It is more difficult, maybe even impossible to implement globalization and free trade while dealing with dictatorships, unstable governments, and failed countries. Sometimes, the so-called democratic countries invade other countries that are not democratic for numerous reasons, which are sometimes obvious and sometimes not so obvious. The reasons often revolve about national security, resource wars, economics, retaliation, and government stability, trade, and globalization.

So what is the message? Too many humans, consuming too many nonrenewable resources in evolving democracies and in dictatorships; generating too much biosphere pollution in accordance with the laws of thermodynamics is not a present situation or future that humans will be able to sustain with any quality of life. Democracies are required for economic trade and growth, globalization, and resource exploitation. However, they must be actual democracies not slowly evolving democracies with corruption, secrecy 
and no democratic transparency, lacking leadership and lacking infrastructure in education, public health, potable water, food safety and security, transportation, legal and justice systems and a lack of citizen involvement. A priority national and international challenge will be to engineer actual stable democratic states, in sufficient time to deal with human population growth and the immense amount of pollution contributing to global climate change. Engineering the correct democracies has been an immense challenge for all countries and some have totally failed to make any progress. These counties will destroy themselves from within. Many citizens and their so-called managers (not leaders) in these failed countries will find themselves in a world they do not understand. Isolation from other countries will only deepen their problems. Their civilizations will contribute very little to humanity. They will not have the capacity to evolve democratic infrastructure nor conduct high-level research, manufacture technologies, and apply it to their needs. This situation is already present. Their currency is worthless or will be worthless, and hence, international trade is more than a challenge. They will need the assistance of the more affluent countries.

Let us engineer the real democracies we need and deserve, so we can have a common humanity and a shared planetary future. The alternative is not a future for our common humanity. Praying to supernatural entities will also not solve the crisis. Let us be on the correct side of decision-making and humanity when future scholars and individuals judge us. 